\title{
Photoluminescence Characteristic of Magnesium Boro-Tellurite doped $\mathrm{Eu}^{3+}$ Ceramic
}

(Ciri Fotoluminesens bagi Magnesium Boro-Telurit dop Seramik $\mathrm{Eu}^{3+}$ )

\author{
NUR ZU IRA BOHARI, R. HUSSIN*,ZUHAIRI IBRAHIM \& HENDRIK O. LINTANG
}

\begin{abstract}
The series samples of $\mathrm{xTeO}-(70-\mathrm{x}) \mathrm{B}_{2} \mathrm{O}_{3}-30 \mathrm{MgO}$ with $\mathrm{O} \leq \mathrm{x} \leq 30$ mol\% have been prepared via the solid-state reaction method. The composition sample of $30 \mathrm{TeO}-4 \mathrm{OB}_{2} \mathrm{O}_{3}-30 \mathrm{MgO}$ were chosen as a doped sample in the composition of $100-\mathrm{y}\left(30 \mathrm{Te} \mathrm{O}_{2}-40 \mathrm{~B}_{2} \mathrm{O}_{3}-30 \mathrm{MgO}\right)-\mathrm{yEu}{ }^{3+}$ with $0.2 \leq \mathrm{y} \leq 2 \mathrm{~mol} \%$ and were heated at $750^{\circ} \mathrm{C}$. The XRD results showed that the major phase was $\mathrm{Mg}\left(\mathrm{Te}_{2} \mathrm{O}_{5}\right)$ while $\mathrm{MgO}\left(\mathrm{B}_{2} \mathrm{O}_{3}\right)_{2}, \mathrm{MgTe}_{6} \mathrm{O}_{13}, \mathrm{Mg}_{2}\left(\mathrm{~B}_{2} \mathrm{O}_{5}\right)$ and $\mathrm{MgB} \mathrm{O}_{7}$ was observed as a minor phase. The small phase of $\mathrm{EuB}_{2} \mathrm{O}_{4}$ and $\mathrm{Eu}_{2} \mathrm{Te}_{4} \mathrm{O}_{11}$ were detected by XRD when the composition of $30 \mathrm{Te} \mathrm{O}_{2}-4 \mathrm{OB}_{2} \mathrm{O}_{3}-30 \mathrm{MgO}$ were doped with $1.5 \%$ of $\mathrm{Eu}^{3+}$. The EDX analysis of $30 \mathrm{TeO} \mathrm{O}_{2}-4 \mathrm{OB}_{2} \mathrm{O}_{3}-30 \mathrm{MgO}$ doped with $1.5 \% \mathrm{Eu}^{3+}$ sample was confirmed the presence of boron $(B)$, magnesium $(\mathrm{Mg})$, tellurium $(\mathrm{Te})$, oxygen $(\mathrm{O})$ and europium $(E u)$ elements. From the FESEM images, the surface morphology of doped $1.5 \% \mathrm{Eu}^{3+}$ samples was agglomerated compared with the undoped sample. The average diameter of the grain size is in the range of 50-100 $\mu \mathrm{m}$. The emission spectra of the Eu $\mathrm{u}^{3+}$-doped $30 \mathrm{TeO} \mathrm{O}_{2}-40 \mathrm{~B}_{2} \mathrm{O}_{3}-30 \mathrm{MgO}$ ceramic consists of intense and sharp lines ranging from 550-725 $\mathrm{nm}$. The luminescence spectra showed that the emission intensity of $30 \mathrm{TeO} \mathrm{O}_{2}-40 \mathrm{~B}_{2} \mathrm{O}_{3}-30 \mathrm{MgO}$ doped with $\mathrm{Eu}^{3+}$ was enhanced with the increase of Eu $\mathrm{u}^{3+}$ ion from 0.2 to $1.5 \mathrm{~mol} \%$, which resulted in enhancement of the red emission of the samples. The longest decay time for $30 \mathrm{TeO}_{2}-40 \mathrm{~B}_{2} \mathrm{O}_{3}-30 \mathrm{MgO}$ doped with $1.5 \mathrm{~mol} \% \mathrm{Eu}^{3+}$ was $0.892 \mathrm{~ms}$.
\end{abstract}

Keywords: Decay curve; magnesium boro-tellurite; photoluminescence

\section{ABSTRAK}

Siri sampel bagi $\mathrm{xTe} \mathrm{O}_{2}-(70-\mathrm{x}) \mathrm{B}_{2} \mathrm{O}_{3}-30 \mathrm{MgO}$ dengan $\mathrm{O} \leq \mathrm{x} \leq 30$ mol\% telah disediakan melalui kaedah tindak balas keadaan pepejal. Sampel dengan komposisi 30Te $\mathrm{O}_{2}-4 \mathrm{OB}_{2} \mathrm{O}_{3}-30 \mathrm{MgO}$ telah dipilih sebagai sampel dop berkomposisi 100-y $(30 \mathrm{TeO}-$ $\left.40 \mathrm{~B}_{2} \mathrm{O}_{3}-30 \mathrm{MgO}\right)-\mathrm{yEu} u^{3+}$ dengan $0.2 \leq \mathrm{y} \leq 2 \mathrm{~mol} \%$ dan telah dipanaskan pada suhu $750^{\circ} \mathrm{C}$. Keputusan XRD menunjukkan fasa major adalah $\mathrm{Mg}\left(\mathrm{Te}_{2} \mathrm{O}_{5}\right)$ manakala $\mathrm{MgO}\left(\mathrm{B}_{2} \mathrm{O}_{3}\right)_{2} \cdot \mathrm{MgTe}_{6} \mathrm{O}_{13}, \mathrm{Mg}_{2}\left(\mathrm{~B}_{2} \mathrm{O}_{5}\right)$ and $\mathrm{MgB} \mathrm{O}_{7}$ dilihat sebagaifasa minor. Fasa yang kecil bagi $\mathrm{Dy}\left(\mathrm{BO}_{2}\right)_{3}, \mathrm{Dy}_{2} \mathrm{Te}_{4} \mathrm{O}_{11}, \mathrm{EuB}_{2} \mathrm{O}_{4}$ and $\mathrm{Eu}_{2} \mathrm{Te}_{4} \mathrm{O}_{11}$ telah dikesan oleh XRD pada komposisi $30 \mathrm{TeO} \mathrm{O}_{2}-40 \mathrm{~B}_{2} \mathrm{O}_{3}-$ $30 \mathrm{MgO}$ dop $1.5 \% \mathrm{Eu}^{3+}$. Analisis EDX bagi sampel $30 \mathrm{TeO} \mathrm{O}_{2}-40 \mathrm{~B}_{2} \mathrm{O}_{3}-30 \mathrm{MgO}$ dop $1.5 \% \mathrm{Eu}^{3+}$ menunjukkan unsur boron $(B)$, magnesium $(\mathrm{Mg})$, telurium (Te), oksigen $(\mathrm{O})$ dan europium (Eu). Daripada imej FESEM, morfologi permukaan bagi sampel dop adalah bergumpal berbanding dengan sampel tidak didop. Diameter purata bagi saiz butiran adalah dalam lingkungan 50-100 $\mathrm{mm}$. Spektrum pancaran bagi $\mathrm{Eu}^{3+}$-dop 30Te $\mathrm{O}_{2}-4 \mathrm{BB}_{2} \mathrm{O}_{3}-30 \mathrm{MgO}$ seramik terdiri garisan yang jelas dan tajam pada julat 550-725 nm. Spektra luminesens menunjukkan keamatan pancaran bagi $30 \mathrm{TeO}_{2}-40 \mathrm{~B}_{2} \mathrm{O}_{3}-30 \mathrm{MgO}_{\mathrm{O}} \mathrm{dop}$ dengan $\mathrm{Eu}^{3+}$ meningkat dengan peningkatan ion $\mathrm{Eu}^{3+}$ daripada $0.2 \mathrm{ke} 1.5 \mathrm{~mol} \%$, menunjukkan peningkatan pancaran merah pada sampel tersebut. Masa pereputan yang paling lama apabila didopkan dengan $1.5 \mathrm{~mol} \% \mathrm{Eu}^{3+}$ pada komposisi $30 \mathrm{TeO}_{2}-40 \mathrm{~B}_{2} \mathrm{O}_{3}-30 \mathrm{MgO}$ adalah $0.892 \mathrm{~ms}$.

Kata kunci: Fotoluminesens; lengkung pereputan; magnesium boro-telurit

\section{INTRODUCTION}

The high optical quality rare earth (RE) ions doped ceramics have been investigated as attractive lighting sources. Ceramics are the best host materials to incorporate high concentrations of dopant ions such as rare earth and transition metal ions besides having thermal and mechanical properties. These ceramic can be fabricated at lower cost and speedy processes in a large variety of sizes and shapes (Lupei et al. 2005; Mohr et al.2008). Borate has been studied extensively due to the physical properties like low melting point, high thermal stability and good solubility (Elfayoumi et al. 2010).
An interesting behavior of the tellurite based is good mechanical strength, chemical durability, no hygroscopic properties and low process temperature (Babu et al. 2007). Among the host materials, boro-tellurite represents favorable compromise of low phonon energy and a relatively high thermal stability, high chemical durability and ease of fabrication (Joshi et al. 2008; Yanmin et al. 2007). Rare-earth elements which act as dopant yield interesting and useful properties in host crystal. Rareearth-doped materials also have potential applications for phosphors, display monitor, x-ray imaging and scintillators (Blasse \& Grabmaier 1994). Moreover, the 
luminescence properties of the ceramic could be improved by doping with rare earth (RE) ions as an activator. $\mathrm{Eu}^{3+}$ doped are commonly used as red emitting materials for field emission technology and LEDs, which exhibit higher luminescence efficiency compared with other luminous materials (Oikawa \& Fujihara 2005). In the present work, magnesium boro-tellurite doped $\mathrm{Eu}^{3+}$ ceramic with various $\mathrm{Eu}^{3+}$ concentration were synthesized by the solid state reaction method. The effect of $\mathrm{Eu}^{3+}$ dopants on the structural and luminescence characteristic are discussed.

\section{EXPERIMENTAL DETAILS}

All the powder samples were synthesized by the solid state reaction method. The starting materials such as of boric acid, $\mathrm{H}_{3} \mathrm{BO}_{3}(99.99 \%)$, tellurium oxide, $\mathrm{TeO}_{2}(99.99 \%)$, magnesium oxide, $\mathrm{MgO}$ (99.99\%) and europium oxide, $\mathrm{Eu}_{2} \mathrm{O}_{3}(99.99 \%)$ were employed as the raw materials. The samples were synthesized according to the compositions of $x \mathrm{TeO}_{2}-(70-x) \mathrm{B}_{2} \mathrm{O}_{3}-30 \mathrm{MgO}$ with $0 \leq x \leq 30$ in appropriate amounts $(\mathrm{mol} \%)$. The percentage of $\mathrm{Eu}_{2} \mathrm{O}_{3}$ from 0.2 to $2 \mathrm{~mol} \%$ was then added into the mixtures. The powders were thoroughly mixed in agate mortar. The mixtures were pressed into pellets using hydraulic press with 10 ton/ $\mathrm{cm}^{2}$ pressure. After pelletized; the samples were heated at $750^{\circ} \mathrm{C}$ for $6 \mathrm{~h}$. The dried pellet was grounded into fine powder. The powders were prepared for the experimental measurement. The structure of the prepared powders was examined by Siemen Diffraction D5000 diffractometer with $\mathrm{CuK}_{\alpha}$ radiation $(\lambda=1.54 \AA)$ and $2 \mathrm{q}$ scan range of 10 to $80^{\circ}$. The PL and lifetime measurements were performed with a Jasco Fluorescence spectrophotometer FP8500 equipped with a 150-W xenon lamp as an excitation source. The surface morphology was examined by field emission scanning electron microscope (FESEM) model SUPRA 55VP. Elemental analysis was carried out by energy dispersive $\mathrm{X}$-ray (EDX) using X-ray detector attached to the FESEM instrument. All the measurements were performed at room temperature.

\section{RESULTS AND DISCUSSION}

The XRD pattern shows the influence of varying composition of the $x \mathrm{TeO}_{2}-(70-x) \mathrm{B}_{2} \mathrm{O}_{3}-30 \mathrm{MgO}$ with $0 \leq x \leq 30 \mathrm{~mol} \%$. It can be observed that all the diffraction peaks in XRD patterns assigned to $\mathrm{Mg}\left(\mathrm{Te}_{2} \mathrm{O}_{5}\right), \mathrm{MgO}\left(\mathrm{B}_{2} \mathrm{O}_{3}\right)_{2}, \mathrm{MgTe}_{6} \mathrm{O}_{13}$, $\mathrm{Mg}_{2}\left(\mathrm{~B}_{2} \mathrm{O}_{5}\right)$ and $\mathrm{MgB}_{4} \mathrm{O}_{7}$, which were well matches with the JCPDS No. 01-073-3922, 01-076-0666, 00-028-0634, 01-086-0531 and 00-031-0787, respectively. Figure 1 shows the intensity of the peaks increases with increasing $x$ $\mathrm{mol} \%$ and the phases appear clearly at $x=30 \mathrm{~mol} \%$. From the XRD results, the major peaks due to $\mathrm{Mg}\left(\mathrm{Te}_{2} \mathrm{O}_{5}\right)$ can be observed followed by $\mathrm{MgO}\left(\mathrm{B}_{2} \mathrm{O}_{3}\right)_{2} \cdot \mathrm{MgTe}_{6} \mathrm{O}_{13}, \mathrm{Mg}_{2}\left(\mathrm{~B}_{2} \mathrm{O}_{5}\right)$ and $\mathrm{MgB}_{4} \mathrm{O}_{7}$ also was observed as a minor peaks. The XRD patterns of $30 \mathrm{TeO}_{2}-40 \mathrm{~B}_{2} \mathrm{O}_{3}-30 \mathrm{MgO}$ doped with $1.5 \%$ of $\mathrm{Eu}^{3+}$ is shown in Figure 2. The pattern shows that a small amount of rare earth ions also can be observed as a minor phase. With the addition of dopant into the sample, the peaks of $\mathrm{EuB}_{2} \mathrm{O}_{4}$ and $\mathrm{Eu}_{2} \mathrm{Te}_{4} \mathrm{O}_{11}$ were included into the XRD pattern. The previous results also showed that rare earth ions phase can be detected (Cheng et al. 2014; Kumar \& Buddhuda 2009; Kunimoto et al. 2013).

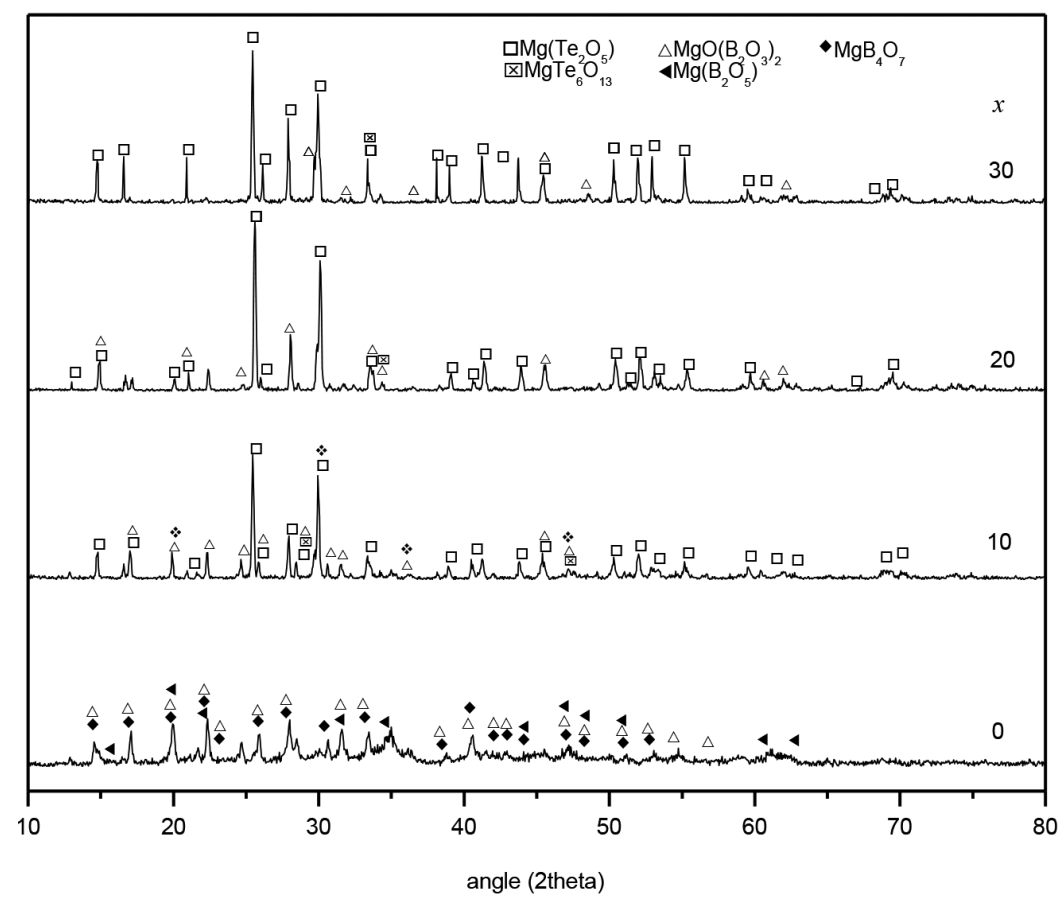

FIGURE 1. X-ray diffraction pattern of $x \mathrm{TeO}_{2}-(70-x) \mathrm{B}_{2} \mathrm{O}_{3}-30 \mathrm{MgO}$ with $0 \leq x \leq 30 \mathrm{~mol} \%$ ceramic sample prepared at $750^{\circ} \mathrm{C}$ 


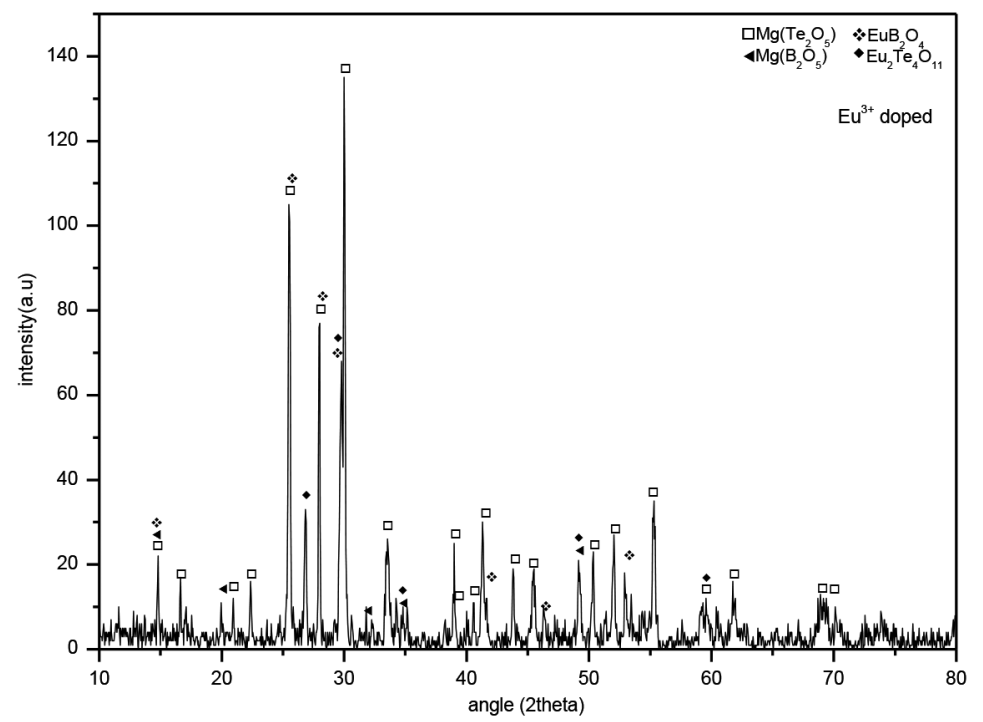

FIGURE 2. X-ray diffraction pattern of $30 \mathrm{TeO}_{2}-40 \mathrm{~B}_{2} \mathrm{O}_{3}-30 \mathrm{MgO}$

doped $1.5 \%$ of $\mathrm{Eu}^{3+}$ ceramic sample prepared at $750^{\circ} \mathrm{C}$

EDX analysis was carried out to confirm the presence of rare earth ion in the samples. Figure 3 shows the EDX spectra of $30 \mathrm{TeO}_{2}-40 \mathrm{~B}_{2} \mathrm{O}_{3}-30 \mathrm{MgO}$ doped $1.5 \%$ of $\mathrm{Eu}^{3+}$. The EDX analysis confirmed the presence of boron (B), magnesium $(\mathrm{Mg})$, tellurium $(\mathrm{Te})$ and oxygen $(\mathrm{O})$ and europium (Eu) elements. Figure 4 shows the FESEM images of $30 \mathrm{TeO}_{2}-40 \mathrm{~B}_{2} \mathrm{O}_{3}-30 \mathrm{MgO}$ doped $1.5 \%$ of $\mathrm{Eu}^{3+}$ at $750^{\circ} \mathrm{C}$. The doped sample has different morphological structures and grain size compared with the undoped sample. The structure of the doped samples is more agglomerated compared with the undoped sample. The samples have an average grain size of 50-100 $\mu \mathrm{m}$.

The excitation spectra of $100-y\left(30 \mathrm{TeO}_{2}-40 \mathrm{~B}_{2} \mathrm{O}_{3}-\right.$ $30 \mathrm{MgO})-y \mathrm{Eu}^{3+}$ ceramic with $0.2 \leq y \leq 2 \mathrm{~mol} \%$ at $750^{\circ} \mathrm{C}$ monitored at $615.68 \mathrm{~nm}$ emission are given in Figure 5.
The broad band from 200 to $350 \mathrm{~nm}$ is attributable to the charge transfer band (СТВ) transition. The СТВ plays an important role in its luminescence. The broad absorption band is assigned to the СТВ of Eu-O (Sun \& Fu 2012), which occurred by electronic transition from the filled $2 p$ orbital of $\mathrm{O}^{2-}$ to the partially filled $4 \mathrm{f}$ orbital of $\mathrm{Eu}^{3+}$. The CTB is related closely to the covalency between $\mathrm{O}^{2-}$ and $\mathrm{Eu}^{3+}$ and the coordination environment around $\mathrm{Eu}^{3+}$ (Tian et al. 2009). It has been reported that СТВ in oxides due to $\mathrm{Eu}^{3+}-\mathrm{O}^{2-}$ interaction might arise (Rao et al. 2008). The sharp lines $363.01 \mathrm{~nm}\left({ }^{7} \mathrm{~F}_{0}-{ }^{5} \mathrm{D}_{4}\right), 382.86 \mathrm{~nm}\left({ }^{7} \mathrm{~F}_{0}-{ }_{-}^{5} \mathrm{G}_{3}\right)$, $396.61 \mathrm{~nm}\left({ }^{7} \mathrm{~F}_{0}-{ }^{5} \mathrm{~L}_{6}\right), 417.14 \mathrm{~nm}\left({ }^{7} \mathrm{~F}_{0}-{ }^{5} \mathrm{D}_{3}\right), 428.74 \mathrm{~nm}\left({ }^{7} \mathrm{~F}_{0}-\right.$ $\left.{ }^{5} \mathrm{D}_{3}\right), 451.43 \mathrm{~nm}\left({ }^{7} \mathrm{~F}_{0}-{ }^{5} \mathrm{D}_{2}\right), 465.78 \mathrm{~nm}\left({ }^{7} \mathrm{~F}_{0}{ }^{-5} \mathrm{D}_{2}\right), 474.72 \mathrm{~nm}$ $\left({ }^{7} \mathrm{~F}_{0}-{ }^{5} \mathrm{D}_{2}\right), 489.07 \mathrm{~nm}\left({ }^{7} \mathrm{~F}_{0}-{ }^{5} \mathrm{D}_{2}\right), 517.16 \mathrm{~nm}\left({ }^{7} \mathrm{~F}_{0}-{ }^{-5} \mathrm{D}_{1}\right), 527.48$ $\mathrm{nm}\left({ }^{7} \mathrm{~F}_{0}-{ }^{5} \mathrm{D}_{1}\right)$ and $537.07 \mathrm{~nm}\left({ }^{7} \mathrm{~F}_{0}-{ }^{5} \mathrm{D}_{1}\right)$ were observed,

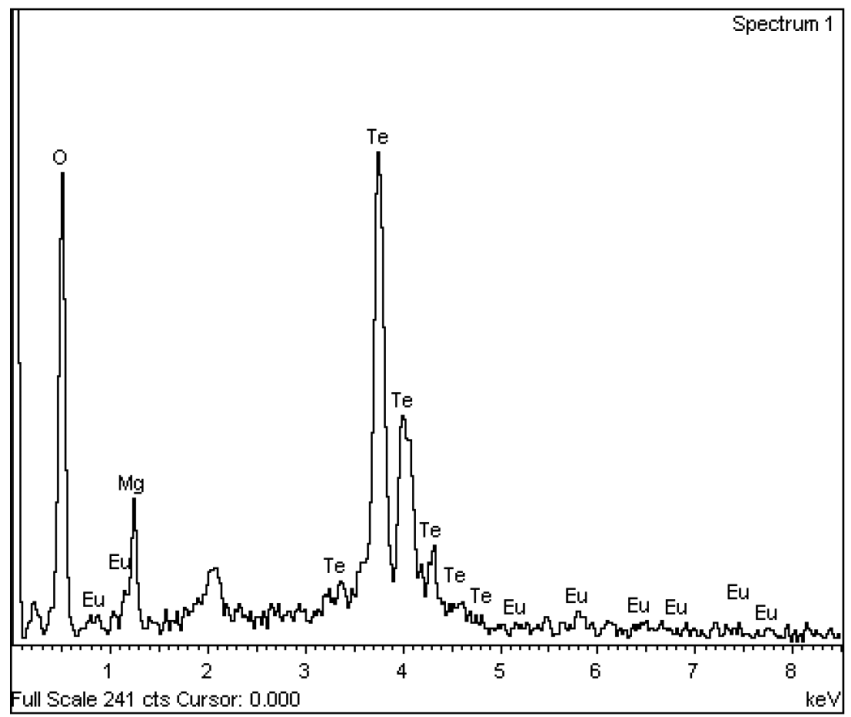

FIGURE 3. EDX spectrum of $30 \mathrm{TeO}_{2}-40 \mathrm{~B}_{2} \mathrm{O}_{3}-30 \mathrm{MgO}$ doped $1.5 \%$ of $\mathrm{Eu}^{3+}$ ceramic sample prepared at $750^{\circ} \mathrm{C}$ 

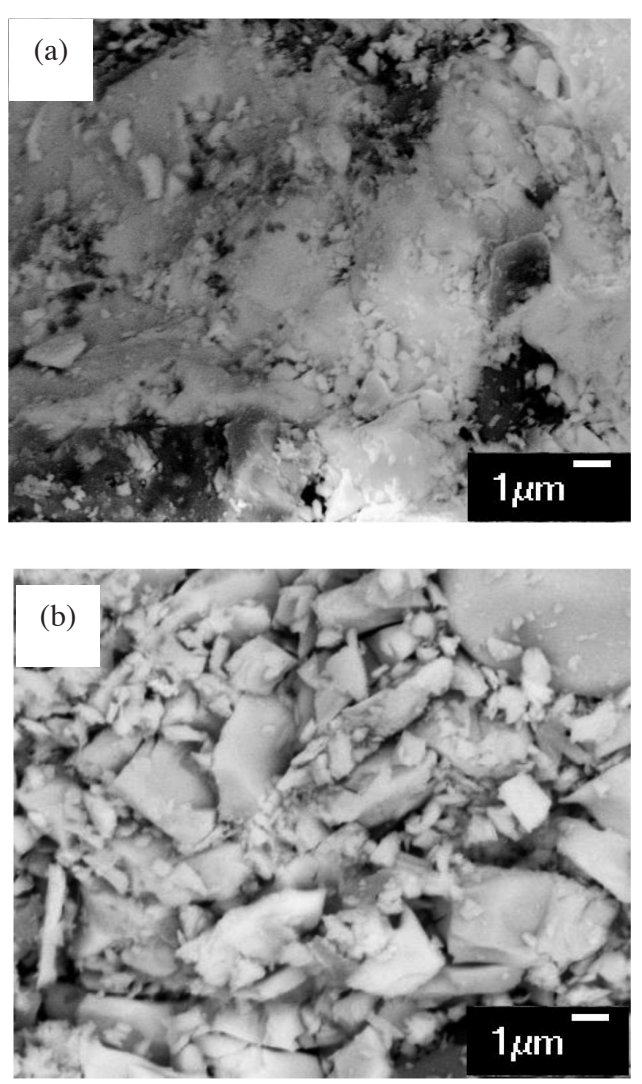

FIGURE 4. FESEM images of $30 \mathrm{TeO}_{2}-40 \mathrm{~B}_{2} \mathrm{O}_{3}-30 \mathrm{MgO}$ (a) $x=30$ (b) $1.5 \%$ of $\mathrm{Eu}^{3+}$ ceramic sample prepared at $750^{\circ} \mathrm{C}$ (magnification: $10 \mathrm{~K} \times$ )

respectively. The adsorbed spectra showed that when the wavelength ranged from $350-550 \mathrm{~nm}$, the sharp peaks originated from the transitions with the $f$-configuration from ${ }^{7} \mathrm{~F}_{0}$ to the excitation states (Visser et al. 1992). No significant shift in peak position was observed for the various $\mathrm{Eu}^{3+}$ ion concentrations. The ${ }^{7} \mathrm{~F}_{0}$ to ${ }^{5} \mathrm{G}_{3}$ at $382.86 \mathrm{~nm}$ and ${ }^{7} \mathrm{~F}_{0}{ }^{-} \mathrm{L}_{6}$ transition at $396.61 \mathrm{~nm}$ were the two strongest absorptions. The prominent excitation band at $396.61 \mathrm{~nm}$ has been chosen for the measurement of emission spectra of $30 \mathrm{TeO}_{2}-40 \mathrm{~B}_{2} \mathrm{O}_{3}-30 \mathrm{MgO}$ doped $\mathrm{Eu}^{3+}$ ceramic. However, the intensities of the peaks in the excitation spectra increased in order of $0.2,0.4,0.6,0.8,1.0,1.5$ and $2 \mathrm{~mol} \%$. As the $\mathrm{Eu}^{3+}$ ion concentration increases, the CTB of Eu-O also increases and is shifted towards the shorter wavelength (higher energy) region.

The luminescence spectrum of $30 \mathrm{TeO}_{2}-40 \mathrm{~B}_{2} \mathrm{O}_{3}$ $30 \mathrm{MgO}$ doped $\mathrm{Eu}^{3+}\left(\mathrm{Eu}^{3+}=0.2,0.4,0.6,0.8,1.0,1.5\right.$ and 2 $\mathrm{mol} \%$ ) ceramic obtained by excitation of $\mathrm{Eu}^{3+}$ at $396.61 \mathrm{~nm}$ are displayed in Figure 6. It can be seen that the emission spectra of the $\mathrm{Eu}^{3+}$-doped $30 \mathrm{TeO}_{2}-40 \mathrm{~B}_{2} \mathrm{O}_{3}-30 \mathrm{MgO}$ ceramic is composed of intense and sharp lines ranging from 550$725 \mathrm{~nm}$, which are related to transition from the excited ${ }^{5} \mathrm{D}_{0}$ level to ${ }^{7} \mathrm{~F}_{J}(J=0-4)$ levels (Li et al. 2012). The strong emission peaks observed at 593.21,615.68 and $701.20 \mathrm{~nm}$ were assigned to the transitions of ${ }^{5} \mathrm{D}_{0}{ }^{-} \mathrm{F}_{1},{ }^{5} \mathrm{D}_{0}{ }^{-} \mathrm{F}_{2}$, and ${ }^{5} \mathrm{D}_{0}$ ${ }^{7} \mathrm{~F}_{4}$. Besides, the weak emission was observed at 642.14 and $654.08 \mathrm{~nm}$ ascribed to the transition of ${ }^{5} \mathrm{D}_{0}{ }^{7} \mathrm{~F}_{3}$. Among these peaks, the red emission peak at $615.68 \mathrm{~nm}$ is more dominant than the other peaks. This peak originates from the electric dipole transitions of ${ }^{5} \mathrm{D}_{0}{ }^{-} \mathrm{F}_{2}$, which indicates that $\mathrm{Eu}^{3+}$ occupies a non-centro-symmetric site (Meng et al. 2012). The luminescence spectra showed that the emission intensity of $30 \mathrm{TeO}_{2}-40 \mathrm{~B}_{2} \mathrm{O}_{3}-30 \mathrm{MgO}$ doped with $\mathrm{Eu}^{3+}$ was enhanced with the increase of $\mathrm{Eu}^{3+}$ ion concentration from 0.2 to $1.5 \mathrm{~mol} \%$, which resulted in enhancement of the red emission of the samples. When the $\mathrm{Eu}^{3+}$ ion concentration continuously increase to $2 \mathrm{~mol} \%$, the emission intensity decreases because of the concentration quenching effect. With the increase of $\mathrm{Eu}^{3+}$ concentration, the proportion of non-radiative energy transfer between nearby $\mathrm{Eu}^{3+}$ ions exceeds the critical value and the luminescence intensity begins to decrease (Cui et al. 2013).

Figure 7 shows the measured fluorescence decay curve of the $30 \mathrm{TeO}_{2}-40 \mathrm{~B}_{2} \mathrm{O}_{3}-30 \mathrm{MgO}$ doped $\mathrm{Eu}^{3+}$ ceramic for various $\mathrm{Eu}^{3+}$ concentrations. With the increase of $\mathrm{Eu}^{3+}$

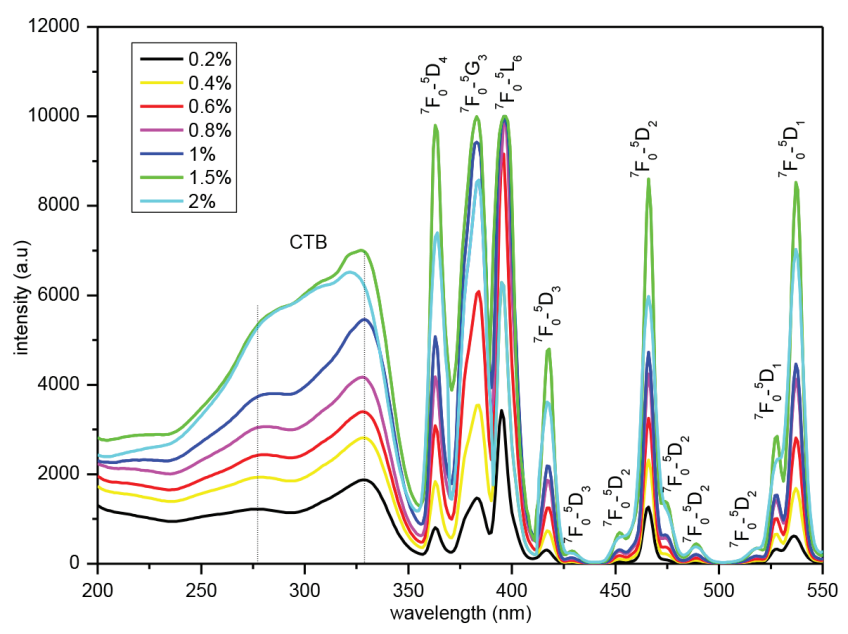

FIGURE 5. Excitation spectra of 100- $x\left(30 \mathrm{TeO}_{2}-40 \mathrm{~B}_{2} \mathrm{O}_{3}-30 \mathrm{MgO}\right)-x \mathrm{Eu}^{3+}$ with $0.2 \leq x \leq 2 \mathrm{~mol} \%$ ceramic sample prepared at $750^{\circ} \mathrm{C}$ 


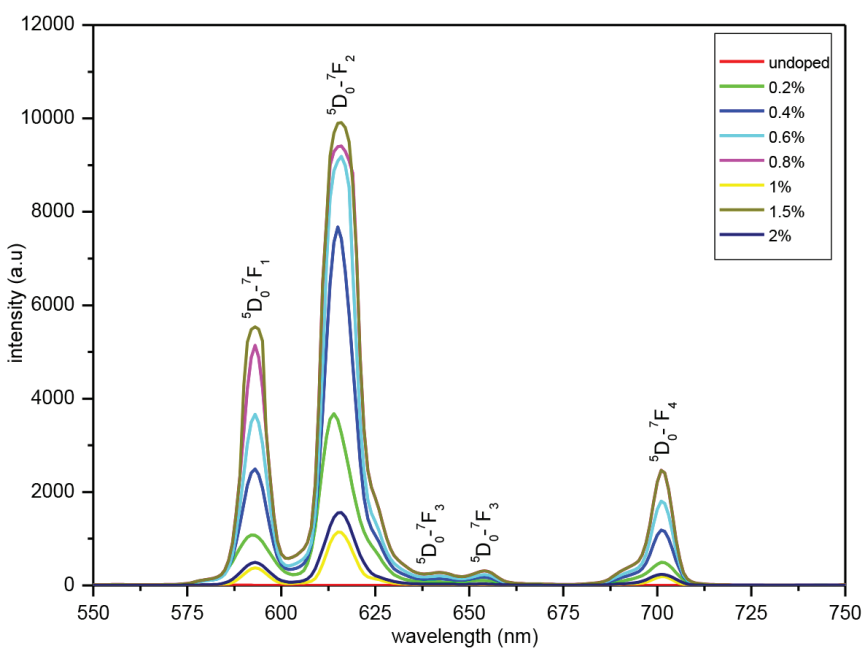

FIGURE 6. Emission spectra of $100-x\left(30 \mathrm{TeO}_{2}-40 \mathrm{~B}_{2} \mathrm{O}_{3}-30 \mathrm{MgO}\right)-x \mathrm{Eu}^{3+}$ with $0.2 \leq x \leq 2 \mathrm{~mol} \%$ ceramic sample prepared at $750^{\circ} \mathrm{C}$

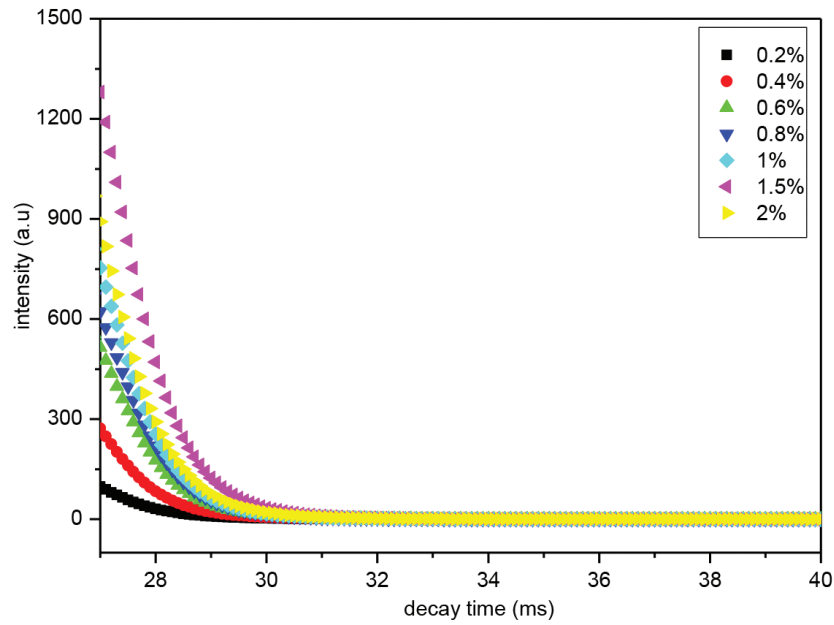

FIGURE 7. Lifetime spectra of $100-x\left(30 \mathrm{TeO}_{2}-40 \mathrm{~B}_{2} \mathrm{O}_{3}-30 \mathrm{MgO}\right)-x \mathrm{Eu}^{3+}$ with $0.2 \leq x \leq 2 \mathrm{~mol} \%$ ceramic sample prepared at $750^{\circ} \mathrm{C}$

concentrations from 0.2 to $1.5 \mathrm{~mol} \%$, the decay time value of $\mathrm{Eu}^{3+}$ ion increased from $0.834 \mathrm{~ms}$ to $0.892 \mathrm{~ms}$ and decrease to $0.846 \mathrm{~ms}$ at $2 \mathrm{~mol} \%$. The longest decay time occurred at $1.5 \mathrm{~mol} \%$ of $\mathrm{Eu}^{3+}$. The sample doped with 2 mol\% $\mathrm{Eu}^{3+}$ had reached a concentration quenching effect and caused shorter lifetime (Fang et al. 2006). The decay curves of $30 \mathrm{TeO}_{2}-40 \mathrm{~B}_{2} \mathrm{O}_{3}-30 \mathrm{MgO}$ doped $\mathrm{Eu}^{3+}$ ceramic values with the various concentrations of $\mathrm{Eu}^{3+}$ ions were listed as shown in Table 1.

\section{CONCLUSION}

In summary, the samples of magnesium boro-tellurite and magnesium boro-tellurite doped $\mathrm{Eu}^{3+}$ ceramic have been prepared using the solid-state reaction method. From the XRD profiles, the major peaks due to $\mathrm{Mg}\left(\mathrm{Te}_{2} \mathrm{O}_{5}\right)$ was observed in each profile followed by $\mathrm{MgO}\left(\mathrm{B}_{2} \mathrm{O}_{3}\right)_{2}$, $\mathrm{MgTe}_{6} \mathrm{O}_{13}, \mathrm{Mg}_{2}\left(\mathrm{~B}_{2} \mathrm{O}_{5}\right)$ and $\mathrm{MgB}_{4} \mathrm{O}_{7}$ observed as weak
TABLE 1 . Decay times for $100-x\left(30 \mathrm{TeO}_{2}-40 \mathrm{~B}_{2} \mathrm{O}_{3}-30 \mathrm{MgO}\right)$ $x \mathrm{Eu}^{3+}$ with $0.2 \leq x \leq 2 \mathrm{~mol} \%$ ceramic sample prepared at $750^{\circ} \mathrm{C}$

\begin{tabular}{cc}
\hline $\begin{array}{c}\text { Concentration of } \mathrm{Eu}^{3+} \\
(\mathrm{mol} \mathrm{\%})\end{array}$ & $\begin{array}{c}\text { Decay time } \\
(\mathrm{ms})\end{array}$ \\
\hline 0.2 & 0.834 \\
0.4 & 0.853 \\
0.6 & 0.858 \\
0.8 & 0.860 \\
1.0 & 0.866 \\
1.5 & 0.892 \\
2.0 & 0.846 \\
\hline
\end{tabular}

peaks. The peaks of $\mathrm{EuB}_{2} \mathrm{O}_{4}$ and $\mathrm{Eu}_{2} \mathrm{Te}_{4} \mathrm{O}_{11}$ were included into the XRD patterns of $30 \mathrm{TeO}_{2}-40 \mathrm{~B}_{2} \mathrm{O}_{3}-30 \mathrm{MgO}$ doped $1.5 \%$ of $\mathrm{Eu}^{3+}$. The morphology of the ceramic studied using the SEM images shows that the particles are agglomerated and the particles are in micron size. From the luminescence 
study, the emission intensity of the $615.68 \mathrm{~nm}$ increases rapidly with $\mathrm{Eu}^{3+}$ concentration up to $1.5 \mathrm{~mol} \%$. When the $\mathrm{Eu}^{3+}$ concentration is above $1.5 \mathrm{~mol} \%$, concentration quenching occurred. The highest value of the decay time was obtained at $1.5 \mathrm{~mol} \%$ of $\mathrm{Eu}^{3+}$. Based on the results of emission spectral, we suggest that these ceramic powders are brightly luminescent and are applicable as novel optical materials.

\section{ACKNOWLEDGEMENTS}

The authors would like to thank the Fundamental Research Grant Scheme (FRGS) under research grant Project Number: Q.J130000.2526.03H97 for the financial support. We would also like to thank the Faculty of Science, Universiti Teknologi Malaysia (UTM) and Institute of Ibnu Sina for the facilities provided.

\section{REFERENCES}

Babu, P., Seo, H.J., Jang, K.H., Kumar, K.U. \& Jayasankar, C.K. 2007. Optical spectroscopy, $1.5 \mu \mathrm{m}$ emission, and upconversion properties of $\mathrm{Er}^{3+}$-doped metaphosphate laser glasses. Journal of the Optical Society of America B 24(9): 2218-2228.

Blasse, G. \& Grabmaier, B.C. 1994. Luminescence Materials. Berlin: Springer-Verlag.

Cheng, L.Y., Dan, P.G., Fei, W., Ming, Y.Z., Ai, L.Z., Xiao, Y.L., Ying, X.L., Xin, Y.L., Hai, B.B. \& Yu, L.P. 2014. On the luminescent properties of $\mathrm{Dy}^{3+}: \beta-\mathrm{Li}_{2} \mathrm{TiO}_{3}$ omment on 'Synthesis and emission analysis of $\mathrm{RE}^{3+}\left(\mathrm{Eu}^{3+}\right.$ or $\left.\mathrm{Dy}^{3+}\right)$ : $\mathrm{Li}_{2} \mathrm{TiO}_{3}$ ceramics'. Ceramics International 40: 11465-11467.

Cui, R., Deng, C., Gong, X., Li, X.\& Zhou, J. 2013.Luminescent performance of rare earths doped $\mathrm{CaBi}_{2} \mathrm{Ta}_{2} \mathrm{O}_{9}$ phosphor. Journal of Rare Earths 31(6): 546-550.

Elfayoumi, M.A.K., Farouk, M., Brik, M.G. \& Elokr, M.M. 2010. Spectroscopic studies of $\mathrm{Sm}^{3+}$ and $\mathrm{Eu}^{3+}$ co-doped lithium borate glass. J. Alloys Compd. 492(1-2): 712-716.

Fang, T.H., Hsiao, Y.J., Chang, Y.S. \& Chang, Y.H. 2006. Photoluminescent characterization of $\mathrm{KNbO}_{3}: \mathrm{Eu}^{3+}$. Materials Chemistry and Physics 100: 418-422.

Joshi, P., Shen, S. \& Jha, A. 2008. Er ${ }^{3+}$-doped boro-tellurite glass for optical amplification in the 1530-1580 $\mathrm{nm}$. Journal of Appl.Phys. 103(8): 083543.

Kumar, G.B. \& Buddhudu, S. 2009. Synthesis and emission analysis of $\mathrm{RE}^{3+}\left(\mathrm{Eu}^{3+}\right.$ or $\left.\mathrm{Dy}^{3+}\right): \mathrm{Li}_{2} \mathrm{TiO}_{3}$ ceramics. Ceramics International 35: 521-525.

Kunimoto, T., Honma, T., Ohmi, K., Okubo, S. \& Ohta, H. 2013. Detailed impurity phase investigation by X-ray absorption fine structure and electron spin resonance analyses in synthesis of $\mathrm{CaMgSi}_{2} \mathrm{O}_{6}$ : eu phosphor. Japanese Journal of Applied Physics 52: 042402.
Li, S., Xu, D., Shen, H., Zhou, J. \& Fan, Y. 2012. Synthesis and Raman properties of magnesium borate micro/nanorods. Materials Research Bulletin 47: 3650-3653.

Lupei, V., Lupei, A. \& Ikesue, A. 2005. Transparent Nd and (Nd, $\mathrm{Yb}$ )-doped $\mathrm{Sc}_{2} \mathrm{O}_{3}$ ceramics as potential new laser materials. Appl. Phys. Lett. 86: 111-118.

Meng, F.G., Zhang, X.M.,Li, H.\& Seo, H.J. 2012. Synthesis and spectral characteristics of $\mathrm{La}_{2} \mathrm{MoO}_{6}: \mathrm{Ln}^{3+}(\mathrm{Ln}=\mathrm{Eu}, \mathrm{Sm}, \mathrm{Dy}$, $\mathrm{Pr}, \mathrm{Tb})$ polycrystals. J. Rare Earths 30(9): 866-870.

Mohr, D., Andrea, S.S., Camargo, D., Schneider, J.F., Quieroz, T.B., Eckert, H., Botero, E.R., Garcia, D. \& Eiras, J.A. 2008. Solid state NMR as a new approach for the structural characterization of rare earth doped lead lanthanum Zirconate titanate laser ceramics. Solid State Sci. 10: 1401-1407.

Oikawa, M. \& Fujihara, S. 2005. Sol-gel preparation and luminescence properties of $\mathrm{CeO}_{2}: \mathrm{Ln}\left(\mathrm{Ln}=\mathrm{Eu}^{3+}\right.$ and $\left.\mathrm{Sm}^{3+}\right)$ thin films. Journal of European Ceramic Society 25: 29212924.

Rao, B.V.,Rambabu,U.\& Buddhudu, S. 2008. Photoluminescence spectral analysis of $\mathrm{Eu}^{3+}$ : Phosphors. Physica B 382: 86-91.

Sun, Y.H. \& Fu, Y.X. 2012. Synthesis and characteristics of nano-size sandwich structure $(\mathrm{Y}, \mathrm{Gd}) \mathrm{BO}_{3}: \mathrm{Eu}^{3+}$ phosphors. J. Luminescence 132: 550-557.

Tian, Y., Qi, X., Wu, X., Hu, R. \& Chen, B. 2009. Luminescent properties of $\mathrm{Y}_{2}\left(\mathrm{MoO}_{4}\right)_{3}: \mathrm{Eu}^{3+}$ red phosphors with flowerlike shape prepared via co-precipitation method. J. Phys. Chem. C 113: 10767-10772.

Visser, O., Visscher, L., Aerts, P.J.C. \& Nieuwpoort, W.C. 1992. Molecular open shell configuration interaction calculations using the Dirac-Coulomb Hamiltonian: The $\mathrm{f}^{6-}$ manifold of an embedded $\mathrm{EuO}_{6}{ }^{9-}$ cluster. J. Chem. Phys. 96(4): 2910.

Yanmin, Y., Baojiu, C., Cheng, W., Guozhong, R. \& Xiaojun, W. 2007. Investigation of modification effect of $\mathrm{B}_{2} \mathrm{O}_{3}$ component on optical spectroscopy of $\mathrm{Er}^{3}+$ doped tellurite glasses. J. Rare Earths 25(1): 31-35.

Nur Zu Ira Bohari, Rosli Hussin* \& Zuhairi Ibrahim Phosphor Research Group, Department of Physics Faculty of Science, University Teknologi Malaysia 81310 Skudai, Johor Darul Takzim

Malaysia

Hendrik O. Lintang

Ibnu Sina Institute for Fundamental Science Studies 81310 Skudai, Johor Darul Takzim

Malaysia

*Corresponding author; email: roslihussin@utm.my

Received: 23 October 2014

Accepted: 5 May 2015 